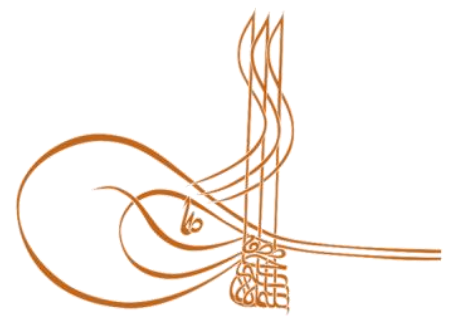

www.turkishstudies.net/economy
Turkish Studies - Economics, Finance, Politics

eISSN: $2667-5625$

Research Article / Araștırma Makalesi

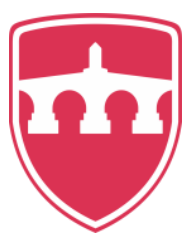

INTERNATIONAL BALKAN

UNIVERSITY

Sponsored by IBU

\title{
Tiebout Hipotezi Çerçevesinde Yerel Mali Değişkenlerin Mekânsal Tercihe Etkisi: Türkiye Örneği
}

\author{
The Effect of Local Fiscal Variables On Spatial Choice In The Framework of the Tiebout \\ Hypothesis: The Case of Turkey
}

\section{Cihan Yüksel*}

\begin{abstract}
The discussion of by which government level and how much local public goods and services should be provided has been one of the important theoretical issues of local government finance. The Tiebut model takes the lead among the hypotheses that explain that local governments have an important role in ensuring efficiency in resource allocation. Based on the assumption that consumer-voters have mobility and full knowledge, the Tiebout model suggests that these individuals would move to the communities that reflect the patterns of consumption on local public goods and services in the best way, and that this moving action would take place until each community reaches optimal size. The model, thus, concludes that local services will ensure efficiency of resource allocation through a private market-like mechanism. The Tiebout model has been led to empirical measurement of many different issues, such as the impact of local fiscal variables on spatial preferences, the public service preferences of individuals, the internal migration motif, the housing prices, and the tax capitalization. The aim of this study is also to test the relationship between local fiscal variables and settlement preferences within the framework of the Tiebout model. Therefore, this study aims to analyze the effects of local fiscal, economic and social variables on spatial choice (net migration rate), using panel data techniques for the 2008-2017 period in 81 provinces of Turkey. In the analysis, it was found that net migration rate has a negative relationship with per capita local tax revenue, per capita local expenditure and crime rate, while a positive relationship with local GDP per capita. And this result corroborates the Tiebout model in terms of local tax revenues.
\end{abstract}

Structured Abstract: The theories of fiscal decentralization or fiscal federalism, which were subsequently included in the public finance literature, were founded on some early public finance studies. According to Musgrave (1959), efforts of economic stability and income distribution, which are the basic functions of the state, should be provided by the central government. However, the efficiency in resource allocation function of the state will be more effective when it is tried to be provided by local governments. Samuelson (1954) states that a central pricing system must be established in order to determine an optimal level of public goods, which is defined as common consumption goods in which an individual's consumption does not reduce the

*Dr. Öğr. Üyesi, Mersin Üniversitesi, İktisadi ve İdari Bilimler Fakültesi, Maliye Bölümü Asst. Prof. Dr., Mersin University, Faculty of Economics and Administrative Sciences, Department of Public Finance ORCID 0000-0003-1959-1245

cihanyuksel@mersin.edu.tr

Cite as/ Atıf: Yüksel, C. (2020). Tiebout hipotezi çerçevesinde yerel mali değişkenlerin mekânsal tercihe etkisi: Türkiye örneği, TurkishStudies-Economy, 15(1), 629-643. https://dx.doi.org/10.29228/TurkishStudies.40112

Received/Geliş: 10 December/Aralık2019

Checkedbyplagiarism software

Accepted/Kabul:25March/Mart 2020

Published/Yayın: 30March/Mart 2020

Copyright $(\mathcal{C}$ INTAC LTD, Turkey

CC BY-NC 4.0 
consumption of other individuals. Because individuals focusing on their own benefit may give false signals by pretending to show less interest in common consumption goods than they actually do. Therefore, taxation should be at the central level. According to Samuelson (1954), different types of "voting" or "signaling" may of course be considered. In other words, there is a solution, but the problem is how to find it. At this point, Tiebout (1956) developed a model in which correct signaling can be achieved for local public goods, which represent a large proportion of public goods. The Tiebout model assumed that local public goods more accurately reflected the preferences of the population than the public goods at the national level, and provided a solution for the level of expenditure on local public goods. According to Tiebout (1956), if all consumer-voters can somehow be forced to present their real preferences for public goods, then amount of these goods and the appropriate benefit tax can be determined.

The model put forward by Tiebout has a number of assumptions (Tiebout, 1956: 419): (1) Consumervoters are fully mobile and move to the community where the patterns of choice they identify are best met; (2) It is assumed that consumer-voters have full knowledge and respond to differences in income and expenditure patterns; (3) There are many communities where consumer-voters may choose to live; (4) Restrictions arising from employment opportunities are not considered. Therefore, it can be assumed that all people live with dividend income; (5) Public services provided do not include positive or negative externalities between communities; (6) There is an optimal size for each community, and this optimum is defined as the number of people in which services can be produced at the lowest average cost; (7) Communities below the optimum size try to attract new residents to reduce average costs. Those above the optimum size do the opposite. Optimum ones try to keep their populations constant.

Under these assumptions, consumer-voters would move to the community that meets their preference patterns. Moving would be carried out from communities above the optimal size to communities below the optimal size. Thus, the act of moving or failing to move would reveal the demand of consumer-voter to public goods and this would replace the classical market criterion of willingness to buy goods in the private sector. Therefore, it is possible to say that the Tiebout model, which shows that there is a local public goods mechanism in which has Pareto optimal results with individual preferences, challenges Samuelson's claim that decentralized choice cannot lead to the efficient providing of public goods.

The aim of this study is to test the relationship between local fiscal variables and settlement preferences within the framework of the Tiebout model. Therefore, this study aims to analyze the effects of local fiscal, economic and social variables on spatial choice (net migration rate), using panel data techniques for the 2008-2017 period in 81 provinces of Turkey.

In our model, which we estimate with the panel EGLS (Estimated Generalized Least Square) method, it is concluded that the net migration rate has a positive correlation with local GDP per capita and a negative relationship with crime rate. In terms of the fiscal variables we use to analyze the Tiebout model, it was found that net migration rate has a negative relationship with per capita local expenditures and per capita local tax revenues.

In terms of local tax revenues, it is possible to say that the Tiebout model is available in Turkey. In other words, consumer-voters prefer to live where lower per capita local tax revenues in Turkey. In terms of local expenditures, the expected result of the Tiebout model could not be fully obtained. It is seen that consumer-voters choose to emigrate from provinces where local expenditures per capita increased, albeit slightly.

However, another important point in terms of local expenditures in the Tiebout model is the type of local public services that are reason of the expenditures. As a matter of fact, according to the Tiebout model, consumer-voters will prefer to live in regions where local public services are close to their preferences. In other words, local expenditure is a qualitative rather than quantitative issue in the Tiebout model. Therefore, a small negative relationship between local expenditure per capita and net migration rate in our panel data analysis does not generally invalidate the Tiebout model.

Of course, there are many other local factors in choosing settlements. Similarly, in terms of consumervoters, many personal factors can also be decisive in making spatial choices. The fact that our analysis was made within the framework of the Tiebout model assumptions and data constraints made it necessary to examine only the relationship between local fiscal variables and spatial preferences.

Keywords: Fiscal Federalism, Fiscal Decentralization, the Tiebout Model, Panel Data Analysis. 
Öz: Yerel kamusal mal ve hizmetlerin hangi yönetim düzeyi tarafından ve ne miktarda sunulması gerektiği tartışması, yerel yönetimler maliyesinin önemli kuramsal konularından biri olmuştur. Kaynak tahsisinde etkinliğin sağlanması konusunda yerel yönetimlerin önemli bir görevi olduğunu açıklayan hipotezlerin başında Tiebut modeli gelmektedir. Tiebout modeli, tüketici-seçmenlerin hareketli olduğu ve tam bilgiye sahip olduğu ön varsayımından hareketle, bu bireylerin yerel kamusal mal ve hizmetler konusunda tüketim kalıplarını en iyi yansıtan topluluklara taşınacaklarını ve bu taşınma eyleminin her topluluk optimal büyüklüğe ulaşana kadar gerçekleşeceğini öne sürmektedir. Böylece model, yerel hizmetlerin özel piyasa benzeri bir mekanizmayla etkin kaynak tahsisini sağlayacağı sonucuna varmaktadır. Tiebout modeli, yerel mali değişkenlerin mekansal tercihlere etkisi, bireylerin kamusal hizmet tercihleri, iç göç motifi, konut fiyatları ve verginin kapitalizasyonu gibi birçok farklı konunun ampirik olarak ölçülmesine kaynaklık etmektedir. Bu çalışmanın da amacı, yerel mali değişkenler ile yerleşim yeri tercihleri arasındaki ilişkiyi Tiebout modeli çerçevesinde test etmektir. Bu nedenle çalışma, Türkiye'de 81 il düzeyinde 2008-2017 dönemi için panel veri tekniklerinden faydalanarak yerel mali, iktisadi ve sosyal değişkenlerin mekânsal tercihe (net göç hızına) olan etkilerini analiz etmeyi amaçlamaktadır. Analizde net göç hızının, kişi başı yerel vergi geliri, kişi başı yerel harcama ve suç oranı ile negatif, kişi başı yerel GSYH ile pozitif bir ilişkiye sahip olduğu tespit edilmiş ve yerel vergi gelirleri açısından Tiebout modelini doğrulayan bir sonuç elde edilmiştir.

Anahtar Kelimeler: Mali Federalizm, Mali Yerelleşme, Tiebout Modeli, Panel Veri Analizi.

\section{Giriş}

Maliye teorisi kamu harcamaları ve vergi analizleri üzerine temellense de, kamusal malların önemli bir kısmının yerel nitelik taşıması yerel yönetimler maliyesi çalışma alanını doğurmaktadır. Nitekim kamusal malların yerelden sunulması kaynak tahsisinde etkinliği kolaylaştıracak ve idari kolaylıklar sağlayacaktır. Yerel kamusal mal ve hizmetler için yapılan kamu harcamalarının finansmanı tartışmaları ise mali yerelleşme ve mali federalizm konularını gündeme getirmektedir. Zira yerel kamu harcamalarının finansmanı için vergi toplama yetkilerinin de yerelde olması bireylerin vergiye gönüllü uyumunu artıracaktır. Ancak vergi toplama yetkisinin yerelleşmesinin bölgeler arası mali dışsallıklara neden olacağı ve gelir dağılımında adalet ile ekonomik istikrar hedeflerinden sapmalara yol açacağı da tartışılan konular arasındadır.

Ülkelerin mali yerelleşme düzeyleri siyasi ve iktisadi yapılarına göre değişmekle birlikte, hemen her ülkede yerel yönetimler kamu sektörünün bir bileşeni olmaktadır. Bu nedenle etkin bir yerel mali yapının oluşturulması önemlidir. Yerel yönetimler maliyesinde etkinlik koşullarının oluşması açısından Charles M. Tiebout tarafindan oluşturulan model bu önemin bir parçasıdır. Tiebout modeli, tüketici-seçmenlerin hareketli olduğu ve tam bilgiye sahip olduğu ön varsayımından hareketle, bu bireylerin yerel kamusal mal ve hizmetler konusunda tüketim kalıplarını en iyi yansıtan topluluklara taşınacaklarını ve bu taşınma eyleminin her topluluk optimal büyüklüğe ulaşana kadar gerçekleşeceğini öne sürmektedir. Böylece model, yerel hizmetlerin özel piyasa benzeri bir mekanizmayla etkin kaynak tahsisini sağlayacağ 1 sonucuna varmaktadır. Her ne kadar Tiebot kendi makalesinde bu ifadeyi kullanmış olmasa da, literatürde "ayaklarıyla oy vermek" şeklinde ifade edilen hipotez, aldığı destekler ve eleştirilerle yerel yönetimler maliyesinin önemli tartışma konularından biri olmuştur.

Tiebout modeli, ampirik açıdan birçok farklı konunun analiz edilmesine kaynaklık etmektedir. Bu çalışmanın da amacı, yerel mali değişkenler ile yerleşim yeri tercihleri arasındaki ilişkiyi Tiebout modeli çerçevesinde test etmektir. Bu nedenle çalışmamız, Türkiye'de 81 il düzeyinde 2008-2017 dönemi için panel veri tekniklerinden faydalanarak yerel mali, iktisadi ve sosyal değiş̧kenlerin mekânsal tercihe (net göç hızına) olan etkilerini analiz etmeyi amaçlamaktadır.

Çalışmamızda öncelikle Tiebout modeli kuramsal olarak açıklanmış, ardından Tiebout modeli çerçevesinde yapılan ampirik literatür incelenmiştir. Çalışmamızın ampirik bölümünde ise, Türkiye'de kişi başı yerel harcamaların, kişi başı yerel vergi gelirlerinin, kişi başı yerel GSYH’nin 
ve yerel suç oranlarının iller düzeyinde net göç oranına etkisi analiz edilmiş ve sonuçlar Tiebout modeli çerçevesinde değerlendirilmiştir.

\section{Yerel Yönetimler Maliyesi ve Tiebout Modeli}

"Geleneksel kamu maliyesi teorisinin ilk yazınında Sax, Wicksell, Lindahl, Musgrave ve Bowen dışında, ekonomistler enerjilerinin çoğunu vergilendirme teorisine harcayarak optimal kamu harcamaları teorisini ihmal etmişlerdir" (Samuelson, 1954: 387). Bir başka ifadeyle, kamu ekonomisinin harcama yönlerini ihmal eden ve sorunun gelir yönünü ele alırken adaleti dikkate almanın önemini vurgulayan kamu maliyesi teorisinin klasik yaklaşımı, gelir-harcama sürecini iktisat teorisi gövdesinin dışında bırakmıştır (Musgrave, 1939: 213).

Kamu harcamalarının yapısı üzerine daha sonraları yapılan çalışmalar ise kamusal malların sunumunu merkezi düzeyde incelemiştir. Yerel kamusal malları ve bunların yerel yönetimler tarafindan sunumunu kamu maliyesi teorisine kazandıran ilk kuşak yazarlar Musgrave, Tiebout ve Oates gibi isimler olmuştur. Özellikle de mali yerelleşme ve mali federalizm kavramlarına vurgu yapan bu çalışmalar içerisinde Tiebout'un geliştirdiği model dikkat çekicidir. Model, tüketiciseçmenlerin tamamen hareketli olması durumunda, gelir-harcama kalıpları belirlenmiş olan uygun yerel yönetimlerin tüketici-seçmenler tarafından yerleşim yeri olarak tercih edileceğini ve bu durumda insanların yerel kamusal mallara olan tercihlerini doğru açıklayarak kaynak tahsisinde etkinliğin sağlanmasına katkıda bulunacağını ifade etmektedir. Tiebout modelinin kuramsal temellerinin yanı sıra ampirik olarak test edildiği bir tartışma alanı da bulunmaktadır. Çalışmanın bu bölümünde iki tartışma alanı da incelenmektedir.

\subsection{Kuramsal Literatür}

Musgrave (1939)'e göre, bireylerin kamusal çıkarların takibinde gönüllü bir ortaklık oluşturmasının tek yolu, üyelerin üyelik maliyetini karşılayacak yeterli büyüklükte bölünebilir faydalar elde etmesi ya da üyelerin maliyetlerde payına düşeni üstlenmeye mecbur edilmesidir. Kamusal mallar bölünemezlik özelliğine sahip olduğundan, bireylerin ödeme güçlerine göre vergilendirilmeye mecbur edilmesi esastır. Bu nedenle, kamusal mallar için yapılan harcamaların optimal seviyesinin özel mallarda olduğu gibi piyasa araçlarıyla belirlenmesi mümkün değildir. Musgrave (1956), bu kamusal mal ve hizmetlerin sunumunda üç temel bütçe fonksiyonu oluşturmuştur: (1) Kamusal ihtiyaçların tatminini sağlama fonksiyonu; (2) Gelir dağılımını düzeltme fonksiyonu; (3) İstikrara katkıda bulunma fonksiyonu. Daha sonraları Musgrave (1959), bu fonksiyonlardan ilkini "kaynak tahsisinde etkinlik" şeklinde ifade etmiş; bu fonksiyonun yerel yönetimler tarafından sağlanmasının daha doğru olacağını ve gelir dağılımında adalet ile ekonomik istikrar fonksiyonlarının ise merkezi yönetim tarafından karşılanması gerektiğini öne sürmüştür.

Samuelson (1954), bir bireyin tüketiminin başka bireylerin tüketimini azaltmadığı ortak tüketim malları olarak tanımladığı kamusal malların optimal bir seviyesinin belirlenebilmesi için merkezi bir fiyatlama sisteminin olması gerektiğini ifade etmektedir. Çünkü kendi faydasına odaklanan bireyler, ortak tüketim mallarına gerçekte sahip olduğundan daha az ilgi gösteriyormuş gibi yaparak yanlış yönlendirmelerde bulunabilirler. Bu nedenle de vergileme merkezi düzeyde olmalı ve fayda teorisine göre uygulanmamalıdır. Samuelson (1954)'a göre elbette farklı "oylama" veya "yönlendirme" türleri düşünülebilir. Bir başka ifadeyle çözüm vardır, ancak sorun onun nasıl bulunacağıdır. Tam da bu noktada Tiebout (1956), kamusal malların büyük bir bölümünü oluşturan yerel kamusal mallar için doğru yönlendirmenin sağlanabileceği bir model geliştirmiştir.

Kamusal mallar için yapılan harcamaların seviyesini belirlemede piyasa tipi bir çözüm olmadığı konusunda Samuelson ve Musgrave'in hemfikir olmasına karşın; kamusal üretimin optimal olamayacağı ön kabulüne sahip olan Tiebout (1956), özel sektörle karşılaştırıldığında milli gelirin oldukça büyük bir bölümünün "optimal olmayan" bir şekilde tahsis edilmesi sorunuyla karş1 karşıya kalındığını iddia etmektedir. Bu nedenle Tiebout (1956), federal harcamalar için geçerli olan Musgrave-Samuelson analizinin yerel harcamalar için geçerli olmadığını göstermeye çalışmış, 
Musgrave ve Samuelson tarafindan yapılan varsayımları ve ele aldıkları temel sorunları yeniden düzenlemiştir. Tiebout modeli, nüfusun tercihlerini ulusal düzeydeki kamusal mallardan ziyade yerel kamusal malların daha doğru yansıttığını varsaymış ve yerel kamusal mallar için yapılan harcama seviyesine yönelik bir çözüm sunmuştur (Tiebout, 1956: 416).

Samuelson ve Musgrave'in temelini oluşturduğu maliye teorisinde kamusal mal ve hizmetlere olan talebin (tüketici ya da seçmen tercihlerinin) belirlenmesi veya bunun kayılt altına alınması sorundur. Tiebout (1956: 417)'a göre, tüm tüketici-seçmenler bir şekilde kamusal mallar için gerçek tercihlerini ortaya koymaya zorlanabilirse, o zaman üretilecek bu malların miktarı ve bu mallardan elde edilen faydaya göre alınacak uygun vergi belirlenebilir.

Musgrave ve Samuelson, harcamaların merkezi hükümet düzeyinde gerçekleştirildiğini dolaylı olarak varsaymaktadırlar. Oysa Tiebout (1956: 418) yerel harcamaların federal harcamalara göre daha büyük bir paya sahip olduğunu, çünkü kamusal mal ve hizmetlerin büyük bölümünü yerel nitelikteki malların oluşturduğunu öne sürmektedir. Bu nedenle, yerel düzeyde yerel kamusal mallara yapılan harcamaların uygun seviyeye yaklaştığından emin olmak için herhangi bir mekanizmanın çalışıp çalışmadığını ortaya koymak önemli bir sorundur. Bu mekanizmayı geliştirmek adına, yaşayacağı bölgeyi seçecek bir şehir sakininin kendi tüketim tercihlerine uyan yerleşim yerlerini seçeceği varsayılmaktadır. Yani tüketici-seçmen, kamusal mallar için kendi tercih şablonunu en iyi karşılayan topluluğu seçmektedir. Bu durum, kamusal malların merkezden sunumu ile yerelden sunumu arasındaki önemli bir farktır. Merkezi düzeyde tüketici-seçmenlerin tercihleri oylamaya dayalı siyasi mekanizmayla belirlenir ve merkezi hükümet bu tercih kalıplarına uyum sağlamaya çalışır. Oysa yerel yönetimlerin gelir ve giderleri az çok bellidir ve tüketiciseçmenler tercihlerini en iyi şekilde karşılayan topluluğa taşınırlar. Topluluk sayısı arttıkça ve topluluklar arasındaki varyans arttıkça, tüketici tercih pozisyonunu tam olarak kavramaya başlayacaktır.

Tiebout'un ortaya koyduğu model bir takım varsayımlara sahiptir (Tiebout, 1956: 419):

- Tüketici-seçmenler tamamen hareketlidir ve belirledikleri tercih kalıplarının en iyi şekilde karşılandığı topluluğa taşınırlar.

- Tüketici-seçmenlerin gelir ve harcama kalıpları arasındaki farklılıklar konusunda tam bilgiye sahip olduğu ve bu farklılıklara tepki gösterdiği varsayılmaktadır.

- Tüketici-seçmenlerin yaşamayı seçebilecekleri çok sayıda topluluk bulunmaktadır.

- İstihdam firsatlarından kaynaklanan kısıtlamalar dikkate alınmamaktadır. Tüm kişilerin temettü geliri ile yaşadığı varsayılabilir.

- Sunulan kamusal hizmetler, topluluklar arasında olumlu veya olumsuz dişsallık içermemektedir.

- Topluluğun eski sakinlerinin tercihlerini izleyen bir şehir yöneticisi tarafindan belirlenen her topluluk hizmet modeli için optimal bir topluluk büyüklüğü vardır. Bu optimum, bu hizmet demetinin en düşük ortalama maliyetle üretilebileceği insan sayısı olarak tanımlanmaktadır.

- Optimum büyüklüğün altındaki topluluklar ortalama maliyetleri düşürmek için yeni sakinleri çekmeye çalışırlar. Optimum boyutun üstünde olanlar tam tersini yapar. Optimumda olanlar ise nüfuslarını sabit tutmaya çalışırlar.

$\mathrm{Bu}$ varsayımlar altında tüketici-seçmenler kendi tercih kalıplarını karşılayan topluluğa taşınacaklardır. Taşınma eylemi, optimal büyüklüğün üstündeki topluluklardan optimal büyüklügün altındaki topluluklara doğru gerçekleştirilecektir. Böylece taşınma veya taşınmama tüketiciseçmenin kamusal mallara olan talebini ortaya koyacaktır ve bu durum özel sektörde bir mal almaya istekli olmanın klasik piyasa ölçütünün yerini alacaktır. 
Her bir bölge, sakinlerinin isteklerini yansıtan bir gelir ve harcama kalıbına sahiptir. $\mathrm{Bu}$ modelde, yerel yönetimlerin tüketici-seçmenlerin tercihlerine "adapte olma" yönünde bir girişimi yoktur. Bunun yerine, optimum sayıda konut sakinini çeken yerel yönetimler, ekonomik sistem tarafından "adapte olunmuş" olarak görülebilir. Tiebout modeli özel bir piyasa ile aynı şekilde optimal tahsisi sağlayan bir yerel harcama modeline benzetildiğinde, "n" sayıda yerel kamusal mal ve "m" sayıda topluluğun olduğu varsayımı altında, " $n$ " sayıda malın her biri için kamusal mal piyasasına olan talep, "m" sayıda topluluğun taleplerinin toplamı olacaktır. Bu toplam talep, tüketici-seçmenlerin gerçek tercihlerini temsil eden talebi (yani, bir şekilde zorunlu tutulursa, ortaya koyacakları talebi) yaklaşık olarak belirleyecektir (Tiebout, 1956: 420).

Tiebout, model sonuçlarının piyasa sonuçlarından farklı olduğunu göstermek için topluluk sayısının sınırsız olduğunu, her topluluğun kamusal mallar için farklı bir harcama kalıbına sahip olduğunu, nüfusun iki katına çıkmasının ihtiyaç duyulan hizmet miktarını da iki katına çıkaracağını varsayarak bir karşılaştırma yapmaktadır. Bu durumda boş bir topluluk, herhangi bir kişinin tercih yapısını yerine getirmeyen bir yer olacaktır. Söz konusu varsayımlar altında tüketici-seçmenler tercihlerini tam olarak karşılayan topluluğa taşınacaktır. Tek bireye sahip olan bir topluluğa izin veren bu modelde talep, normal piyasa güçleri tarafindan belirlenen taleple aynı olacaktır. Ancak bu model pek mantıklı değildir, çünkü topluluk sayısı belirsizdir. Topluluk sayısının nüfusa eşit olmamasının hiçbir nedeni yoktur, çünkü her seçmen kendi tercihlerine tam olarak uyan bir topluluğu bulabilir. Bazı sosyolojik değişkenler belirtilmediği sürece, her bireyin kendi belediye yönetimini oluşturması, kamusal malların tahsis sorununu çözmede yetersiz olabilir. Dolayısıyla varsayımları değiştirilmiş bu model gerçeklikten oldukça uzaktır (Tiebout, 1956: 421).

Tiebout'un ana varsayımlarının geçerli olduğu modelde optimal nüfusa sahip bir topluluğun ilave miktarda insan tarafından tercih edilmesi durumunda, insanlar bu alana taşınamadıkları için bir sonraki en iyi ikameyi kabul etmek durumunda kalacaklardır. Tam bir ikame bulunursa, sorun yoktur. Eğer bir ikame bulunamazsa, o zaman optimal tercih pozisyonuna ulaşamama ve daha düşük bir pozisyonun ikamesi, bir derece meselesi haline gelir. Benzer gelir ve gider kalıplarına sahip bir dizi topluluk olduğu sürece, çözüm ideal "piyasa" çözümüne yaklaşacaktır (Tiebout, 1956: 421).

Bu modelin tahsis sonuçlarını göstermek için iki ilgili noktaya değinilmesi gerekmektedir: (1) Kamu hizmetlerinden birinin maliyetindeki değişiklikler, üretilen miktarda değişikliklere neden olacaktır; (2) Bir topluluktan bir topluluğa taşınmanın maliyetleri dikkate alınmalıdır. Bu iki unsuru örneklemek adına, Tiebout yerel düzeyde sunulan bir cankurtaran hizzmetini ele almıştır. Örnekte, ülke genelinde cankurtaranların ücretlerini yükseltmeyi organize ettiği ve bunu başardığ varsayılmaktadır. $\mathrm{Bu}$ durumda plajları olan topluluklardaki toplam vergiler artacaktır ve plajlara büyük ölçüde kayıtsız kalan sakinler bir karar vermek zorunda kalacaklardır. Bu ilave vergiden elde edilen tasarrufun, az sahili olan veya hiç sahili olmayan bir topluluğa taşınmanın maliyetine eşdeğer olup olmadığı önemlidir. Açıkçası bu karar, uygun bir ikame topluluğun mevcudiyeti ve bu topluluklar arasındaki birçok faktöre bağlıdır. Yeterli sayıda insan, plajları olan toplulukları terk edip plajları olmayan topluluklara taşınırsa, kullanılan toplam cankurtaran hizmet miktarı düşecektir. $\mathrm{O}$ zaman bu modeller, özel piyasadaki benzerlerinin aksine, talebin kayıt maliyeti kadar hareketliliğe sahiptir. $\mathrm{Bu}$ maliyet ne kadar yüksek olursa, diğer değişkenler sabitken (ceterisparibus), kaynakların tahsis edilmesi o kadar az optimal olacaktır. Aslında talebin kaydedilmesinin maliyeti, ekonomiye mesafenin (space) girmesiyle ortaya çıkmaktadır. Bu durum özel piyasa ile benzerlik göstermektedir. Üretim fonksiyonları genel olarak azalan faktör getirileriyle birlikte ölçeğe göre sabit getirileri gösteriyorsa ve kayıtsızlık eğrileri her zaman dışbükey ise optimum bir çözüm mümkündür. Üretim tarafında, şehir yöneticilerinin etkin davranışları ya da diğer topluluklardan kaynaklanan rekabet yoluyla toplulukların üretim maliyetlerini asgari düzeyde tutmak zorunda kaldıkları varsayılmaktadır. Talep tarafında ise, veri fiyatlar ve vergiye göre en yüksek kayıtsızlık seviyesine ulaşmak için rekabetçi bir alıcı olan her bireyin, sosyal azami konumun büyük çözümüne bir görünmez el tarafından yönlendirildiği 
söylenebilir. Böylece tüketicinin mekânsal bir ekonomideki tercihlerini açı̆̆a vurmaktan kaçınmasının bir nedeni olmayacaktır. Mekânsal hareketlilik, yerel kamusal malların özel piyasanın alışveriş gezisine benzer bir şekilde sunulmasına neden olacaktır (Tiebout, 1956: 421-422).

Tiebout modelinde topluluklar arasında kamusal mal ve hizmetlerin dışsallıklarının olmadığı varsayımı tartışmalı bir konudur. Elbette analizi kolaylaştırmak adına yapılmış olan bu varsayımın gerçekte olmadığını Tiebout da vurgulamakta ve topluluklar arasındaki olumlu ve olumsuz dişsallıkların yeterli öneme sahip olduğu durumlarda, bir çeşit entegrasyonun söz konusu olabileceğini öne sürmektedir. Ancak yine de Tiebout (1956: 423)'a göre gerçek hayatta, aynı sosyoekonomik tercihleri yansitan topluluklar komşu olduğu için, olumsuz dışsallıklar en aza indirilmektedir. Klasik ekonomik refah temelinde, belediye entegrasyonu ancak herhangi bir hizmetin aynı toplam maliyette ve başka bir hizmet azalmadan gerçekleştirilmesi durumunda kabul edilebilir. Sosyal refah fonksiyonu bilinmediği sürece, sunulan hizmetlerden bir veya daha fazlasında bir azalma ile birlikte genel bir maliyet düşüşü ekonomik zeminde haklı gösterilemez. Örneğin, yerel polis yerine büyükşehir polis teşkilatını savunanlar, durumlarını tamamen ekonomik zeminde gösteremezler. Topluluklardan biri, entegrasyon sonrasında daha önce aldıklarından daha az polis koruması alacaksa, entegrasyon tüketicilerin seçiminin bozulması olarak kabul edilebilir.

Bireysel tercihlerin Pareto etkin sonuç verdiği bir yerel kamusal mal mekanizması olduğunu gösteren Tiebout modelinin, Samuelson'un adem-i merkeziyetçi tercihin kamusal malların etkin sunulmasına neden olamayacağı iddiasına meydan okuduğunu söylemek mümkündür.

Oates, bazı yazarların Tiebout modelini mali federalizm teorisinin merkezi olarak görmesini abartılı bulmuştur. Oates, hanehalkı hareketliliği olmasa bile mali federalizmin birinci kuşak teorisinin yine geçerli olacağını ve yerel kamusal malların adem-i merkeziyetçi sunumu için bir mantık oluşturulabileceğini düşünmektedir. Bu açıdan bakıldığında, Tiebout hipotezinin rolü, adem-i merkeziyetçi finansmanın sağladığı refah kazanımlarını artırmaktır. Oates'e göre Tiebout modeli, yerel kamusal hizmetlerin adem-i merkeziyetçi sunumu fikrini güçlendirmektedir, ancak bu durum hikayenin sadece bir kısmıdır (Oates, 2005: 354).

Tiebout modeline getirilen eleştiriler daha çok varsayımlarının gerçekten uzak olması yönünde olmuştur. Oates (1981), Tiebout'un saf modelinin gerçekçi olmayan varsayımlara sahip olduğunu söylemektedir. Özellikle de, sadece mali hususlara cevap olarak yerel bölgeler arasında masrafsız bir şekilde hareket eden bir başıboş tüketiciler dünyasının varsayılması eleştirilmektedir. Tiebout'un anlattığı hanehalkı, bir istihdam mahalline taşınmanın maliyetleriyle veya mali olmayan diğer bağlarla kısıtlanmamıştır. Dahası, sistemdeki her yerel bölgeye giriş, ilave bir tüketiciye hizmet etme maliyetine eşit bir vergi fiyatıyla karşılanmalıdır. Bu nedenle model bazı cazip sonuçlar ortaya çıkarsa da, tüketici davranışı ve kurumsal yapının doğasını yansıtacak taleplerden söz etmek oldukça zordur. Mesele, gerçek dünyadaki yerel sektörün Tiebout benzeri olup olmadığıdır (Oates, 1981: 93).

\subsection{Ampirik Literatür}

Tiebout modeli, yerel mali değişkenlerin mekansal tercihlere etkisi, bireylerin kamusal hizmet tercihleri, iç göç motifi, konut fiyatlanı ve verginin kapitalizasyonu gibi birçok farklı konunun ampirik olarak ölçülmesine kaynaklık etmektedir. Bazı araştırmacılar Tiebout modelinin sonuçlarından birini veya birkaçını test etmeye çalışırken, bazıları ise varsayımlarını test etmeye çalışmıştır. Tek bir kritere dayanarak Tiebout modelini bütünüyle analiz etmek mümkün değildir. Bu nedenle Dowding, John ve Biggs (1994), ekonomistler, siyaset bilimciler ve nüfus bilimcilerin Tiebout modeliyle ilişkili çalışmalarını beş ana grupta toplamıştır: şehir boyutlu yorumlar, homojenlik yorumları, kapitalizasyon çalışmaları, göç çalışmaları ve mikro-düzeyli testler. Çalışmada, bu geniş literatürün daha çok mali verilere sahip olanlarının bulgularına yer verilmiştir. 
Oates (1969), Amerika Birleşik Devletleri’nin New Jersey eyaletindeki 53 belediye için Tiebout hipotezini vergi kapitalizasyonu çerçevesinde test etmiştir. Emlak vergisi oranı, öğrenci başına eğitim harcamaları, en yakın büyükşehre (Manhattan'a) uzaklık, ev sahibi başına oda sayısı, 1950 'den sonra inşa edilen evlerin yüzdesi, ortanca aile geliri, yıllık geliri 3.000 Dolardan az olan ailelerin topluluktaki yüzdesi gibi değişkenlerin emlak değerine etkisinin en küçük kareler yöntemiyle incelendiği çalışmada, yerel emlak değerlerinin efektif vergi oranı ile negatif ve harcama ile pozitif korelasyona sahip olduğu sonucuna ulaşılmıştır. Katsayıların büyüklüğü, yerel kamu hizmetlerindeki bir artışın emlak vergilerindeki bir artışa eşlik edemediğini ve vergilerdeki artışın yükünün azalan emlak değerleri şeklinde kapitalize edildiğini göstermektedir.

Edel ve Sclar (1974), Oates'in kapitalizasyon yaklaşımını Tiebout hipotezinde yer alan bir yerel kamusal mal piyasasındaki arz uyumunu dikkate almak üzere genişletmektedir. Çalışmada Oates'in tek dönemli kesit analizinin gösterdiği talep koşullarının, Tiebout'un arzın uzun vadede dengede olmadığ1 bir durumdaki hipotezine yaklaştığ1 gösterilmiştir. Amerika Birleşik Devletleri'nin Boston bölgesindeki ardı ardına beş sayım dönemi boyunca (1930, 1940, 1950, 1960, 1970) vergilerin, okul harcamalarının ve yol bakım harcamalarının kapitalizasyonunun analizi, yerel kamusal mallar için diğer tüm piyasalarda değil, okullaşma piyasasında dengeye doğru bir hareket olduğunu göstermektedir. Tahmin edilen katsayılar Oates'in savaş sonrası döneme ilişkin bulgularına yüzeysel olarak benzemektedir. Vergi oranı kapitalizasyonu tüm yıllarda negatiftir ve 1940, 1950 ve 1970 için anlamlıdır. Öğrenci başına okul harcaması savaş sonrası her üç nüfus sayımında da olumlu bir şekilde kapitalize edilmiştir. Bununla birlikte, 1960 ve 1970 için etki \%1 düzeyinde istatistiksel olarak anlamlı değildir ve 1950'den niceliksel olarak daha küçüktür. 1930 ve 1940 için okul harcamasının katsayısı anlamlı değildir ve aslında işareti negatiftir. Otoyol bakım harcamaları herhangi bir dönemde anlamlı bir şekilde kapitalize edilmemektedir.

Cebula (1974), Amerika Birleşik Devletleri’nde 1965-1970 dönemi için yaptı̆̆ analizde refah yardımları, servet vergisi, kişi başı gelir, işsizlik ve iklim (havaların soğukluğu) gibi değişkenlerin eyalet net göç oranı üzerindeki etkilerini 1rk, yaş ve cinsiyet durumlarına göre test etmiş ve Tiebout hipotezini destekleyen sonuçlar elde etmiştir.

Cebula (1978), yine Amerika Birleşik Devletleri'nde 1965-1970 dönemi için yaptığ analizde bu sefer kişi başı kazançlar, işsizlik oranı, refah yardımları, kişi başı servet vergisi, tam zamanlı öğrenci başına kamusal eğitim harcamaları ve dört kişilik bir aile için ortalama konut maliyeti gibi değişkenlerin eyalet net göç oranı üzerindeki etkilerini test etmiş ve yine Tiebout hipotezini destekleyen sonuçlar elde etmiştir.

Munley (1982), Amerika Birleşik Devletleri'nin New York eyaletindeki 54 okul bölgesi için 1975-1976 akademik döneminde şehir dış1 okul bölgeleri, nüfus ve konut değerlerinin seçmen taleplerine etkisini en küçük kareler yöntemiyle test etmiştir. Tiebout hipoteziyle dolaylı ilişkili bu analize göre bireyler yerleşim yeri tercihlerini en azından ilk ve orta öğretimle ilgili kamusal hizmetlere göre belirlemektedir.

Grubb (1982)'a göre Tiebout modeli, bazı varsayımlar altında toplulukların gelir ve tercihlerle ve belki de ırk, arazi kullanımı ve diğer topluluk özellikleriyle giderek daha homojen olacağını ifade etmektedir. Bu nedenle çalışma, 1960-1970 döneminde Amerika Birleşik Devletleri'nin Boston bölgesi toplulukları arasındaki değişiklikleri tanımlayan denklemlerle artan homojenlik hipotezini test etmiştir. Sonuçlar, ayrımcılığın gelire bağlı olarak ve (çok daha zayıf bir şekilde) yaşa bağlı olarak artmakta olduğunu doğrulamaktadır, ancak diğer topluluk özellikleri belirgin bir eğilim göstermemektedir. Denklemler sistemi topluluğun özelliklerini tahmin etmek için kullanılmaktadır ve bu tahminler kamu harcamalarında daha fazla eşitsizlik eğilimi olduğunu doğrulamaktadır. Çalışmanın sonuçları, Tiebout modelinde Pareto optimalitenin sağlanamayacağı ve herhangi bir etkin durumun daha büyük eşitsizlikler pahasına gerçekleşebileceğini göstermektedir. 
John vd. (1995), yerel vergi ve hizmetlerin coğrafi hareketlilik üzerindeki etkisini incelemek amacıyla dört Londra ilçesinde hanehalkının taşınma kararları konusunda anket uygulaması yapmıştır. Vergilerin ve kamu hizmetlerinin taşınma kararlarında önemli faktörler olması, modelin davranışsal varsayımlarını desteklemektedir. Anket katılımcılarının düşük vergi ve iyi hizmete sahip ilçelere taşınması ve bunu bir taşınma nedeni olarak ifade etmesi Tiebout mantığına uymaktadır.

Percy vd. (1995), yerel yönetim politikalarından memnun olmayan vatandaşların daha iyi vergi ve hizmetler sunan başka bir yere taşınma güdüsüne sahip olduğu varsayımını modellemiştir. Çalışma, Amerika Birleşik Devletleri'nin Wisconsin eyaletinde bölgenin en büyük iki ilçesinde bulunan elliden fazla topluluktaki (büyük bir merkezi şehir dâhil) göçmenlerle yapılan anketlerden elde edilen verileri kullanarak hem taşınma kararını hem de yeni bir konut seçimini etkileyen faktörleri incelemiştir. Ampirik bulgular Tiebout modelinin beklentilerini desteklemekte, vergi ve kamu hizmeti faktörlerinin bir bölgeden diğerine geçenler için yeni bir ikamet seçimini önemli ölçüde etkilediğini göstermektedir.

Nechyba ve Strauss (1998), yerel kamusal hizmetlerin düzeyi ve topluluğa giriş fiyatlarının bireysel mekân seçimlerine doğrudan etkisini analiz etmiştir. Modelde kamusal eğitim, yerel konut ve vergi fiyatları gibi yerel mali değişkenler ile suç oranları, büyükşehirden uzaklık ve ticari faaliyet dereceleri gibi diğer topluluk özellikleri yoluyla bireysel topluluk seçimleri açılanmaya çalışılmıştır. Model, öğrenci başına yerel kamusal eğitim harcaması ve topluluğa giriş fiyatları gibi değişkenlerin hanehalkının mekânsal tercihlerinde önemli bir rol oynadığı sonucuna varmıştır.

Sakashita (1999), Tiebout hipotezinin dinamik bir formülasyonunu denemiş ve bu dinamik modelin özelliklerini analitik olarak ve nümerik olarak incelemiştir. Çalışmada üç sonuca varılmıştır: (1) Heterojen birey grupları arasında kamusal mallar için tercih yoğunluğu ve gelir desteği arasındaki ilişki, dinamik sürecin çalışmasında ince bir fark yaratmaktadır; (2) Dinamik sürecin nihai sonuçları, sürecin başladığı ilk koşula büyük ölçüde bağlıdır; (3) Tiebout'un, heterojen bireylerin ayrı yaşam alanları ve nihai dengenin optimalitesi ile ilgili varsayımları mutlaka garanti edilemez.

Sakashita ve Hirao (1999), Tiebout hipotezini Japon şehirlerine ampirik olarak uygulamaktadır. Tokyo metropol bölgesinde 117 şehir ve Osaka metropol bölgesinde 72 şehir, kamu harcama yoğunluğunu açıklayıcı değişkenler olarak kullanmak amacıyla sekiz kümeye ayrılmıştır. Kişi başına düşen gelir, nüfus yoğunluğu ve kümelere karşılık gelen kukla değişkenlerin her bir kentin arsa fiyatı ile ilişkisi incelenmiştir. Kukla değişkenlerin katsayılarının yüksek istatistiksel anlamlılığ 1 , farklı tercihlere sahip kişilerin farklı kamu harcama kalıplarına göre tercih ettiği şehirlerin sınıflandırılmasının anlamlılığı olarak düşünülebilir. Böylece yazarlar Tiebout hipotezinin Japon büyükşehir bölgelerindeki şehirlere uygulanabilir olduğu sonucuna varmışlardır.

Banzhaf ve Walsh (2008), Amerika Birleşik Devletleri'nin California eyaleti için 19902000 dönemine ait verilerle bir bölgesel denge modeli kullanarak Tiebout hipotezini test etmiştir. Model, kamusal mallarda dışsal iyileştirmeler yaşayan bölgelerdeki nüfus yoğunluğunun artmasını ve büyük iyileştirmeler için nispi ortalama gelirlerin artmasını öngörmüştür. Bu hipotezleri değişen hava kalitesi bağlamında test ederek ailelerin çevre kalitesi için "ayaklarıyla oy kullandıkları" fikrine güçlü ampirik destek sağlamışlardır.

Tiebout modelini elbette farklı yerel vergi oranlarının uygulandığ 1 federal yapılı ülkeler için analiz etmek daha kolaydır. Ancak farklı kişi başı yerel vergi gelirlerine, farklı kişi başı yerel harcamalara, farklı yerel hizmet kompozisyonlarına sahip olan üniter yapılı ülkeler için de Tiebout modeli analiz edilebilir. Zira bölümün başında da belirtildiği gibi, Tiebout modeli çerçevesinde birbirinden bağımsız birçok farklı konu incelenmeye açıktır. 


\section{Türkiye'de Tiebout Modelinin Test Edilmesi}

Tiebout modeli her ne kadar mali federalizm çerçevesinde hazırlanmış olsa da, mali yerelleşme çerçevesinde federal olmayan ülke yapıları için de test edilebilir. Buradaki esas amaç, bireylerin mekânsal yerleşim tercihlerinin belirlenmesinde yerel mali değişkenlerin belirleyici olup olmadığının test edilmesidir. Bir başka ifadeyle, yerel harcamalar ve yerel vergi gelirlerinin bireylerin yaşadığı yer tercihlerine bir etkisinin olup olmadığının tespit edilmesi, Tiebout modelinin analizi açısından önemlidir. Söz konusu amacı gerçekleştirmek üzere, çalışmamızda 81 il düzeyinde 2008-2017 dönemi için Tiebout modeli test edilmiştir. Panel veri yönteminin kullanıldığı modelimizin denklemi aşağıdaki gibidir:

$$
N G H_{i t}=\beta_{0}+\beta_{1} Y H_{i t}+\beta_{2} Y V G_{i t}+\beta_{3} Y Y_{i t}+\beta_{4} S O_{i t}+\varepsilon_{i t}
$$

Modelde $N G H$, net göç hızını; $Y H$, kişi başı yerel harcamayı; $Y V G$, kişi başı yerel vergi gelirini; $Y Y$, kişi başı yerel GSYH'yi; $S O$, suç oranını ve $\varepsilon$ ise hata terimini ifade etmektedir. Modelde, $i=1,2, \ldots, N$ yatay kesit birimlerini (yani 81 ili) ve $t=1,2, \ldots, T$ zaman boyutunu göstermektedir.

(1) nolu denklemde bağımlı değişken olarak nüfus yerine net göç hızının kullanılmasının nedeni, doğum ve ölüm gibi faktörlerin de nüfus değerini etkiliyor olması ve buna bağlı olarak nüfus değişkeninin yerleşim tercihlerini göstermede yetersiz kalmasıdır. Bu nedenle yerleşim tercihlerini doğrudan yansıtan net göç hızı bağımlı değişken olarak kullanılmıştır. Net göç hızı, illerin aldığı göç ile verdiği göç arasındaki farkı ifade eden net göç değerinin o ilin nüfusuna bölünmesi sonucunda bulunan orandır. Söz konusu değişkenin verileri TÜíK (2019c) kaynağından elde edilmiştir.

Modelde kullanılan bağımsız değişkenler üç gruba ayrılmaktadır: Mali değişkenler, iktisadi değişken ve sosyal değişken. Kişi başı yerel harcamalar ve yerel vergi gelirleri gibi mali değişkenler Tiebout modelinin analiz edilmesini sağlayacak ana değişkenlerdir. İktisadi değişken olarak kullanılan kişi başı yerel GSYH ve sosyal değişken olarak kullanılan suç oranı ise modelin açıklayıcılığını artırmak amacıyla tercih edilmiştir. Nitekim bir ilin yerleşim tercihlerinin belirleyicileri arasında o ilin iktisadi gelişmişlik düzeyi ve suç oranı da önemli birer faktördür. Tiebout (1956: 419), modelinin varsayımlarını açıklarken istihdam firsatlarının yarattığı kısıtları göz ardı etmiştir. Bu nedenle denklemde kullanılan iktisadi ve sosyal değişkenler Tiebout modelini yorumlamada belirleyici olmayacaktır.

Kişi başı yerel harcama ve kişi başı yerel vergi geliri değişkenlerinin verileri, T.C. Hazine ve Maliye Bakanlığı Muhasebat Genel Müdürlüğü (2019) kaynağından alınan iller itibariyle mahalli idareler bütçe giderleri ve vergi gelirlerinin TÜİK (2019a) kaynağından alınan TÜFE $(2010=100)$ kullanılarak deflate edilmesi ve ilin ilgili yılındaki nüfusuna oranlanması yoluyla elde edilmiştir. Kişi başı yerel GSYH değişkeninin verileri, TÜIKK (2019d) kaynağından alınan il bazında GSYH değerlerinin TÜFE $(2010=100)$ kullanılarak deflate edilmesi ve TÜİK $(2019 b)$ kaynağından alınan ilgili yılın il nüfusuna oranlanması yoluyla elde edilmiştir. Suç oranı değişkeninin verileri ise, TÜiK (2019e) kaynağından alınan iller itibariyle suç miktarının ilgili ilin nüfusuna oranlanmasıyla elde edilmiştir.

Değişkenlere ait açıklayıcı istatistikler Tablo 1'de gösterilmektedir.

Tablo 1: Değişkenlere Ait Açıklayıcı İstatistikler

\begin{tabular}{|c|c|c|c|c|c|}
\hline Değişkenler & Gözlem & Minimum & Maksimum & Ortalama & Standart Sapma \\
\hline$N G H$ & 810 & -0.1190 & 0.1215 & -0.0030 & 0.0131 \\
\hline$Y H$ & 810 & 1.1321 & 19.2754 & 7.0092 & 2.2606 \\
\hline$Y V G$ & 810 & 0.0299 & 1.9720 & 0.5089 & 0.3477 \\
\hline$Y Y$ & 810 & 45.2614 & 368.8276 & 139.0482 & 51.5545 \\
\hline$S O$ & 810 & 0.0002 & 0.0044 & 0.0017 & 0.0002 \\
\hline
\end{tabular}

Turkish Studies -Economy, 15(1) 
Türkiye'de 81 il ve 2008-2017 dönemine ait veriler kullanılarak, Tiebout modelini test etmek amacıyla panel veri analiz tekniklerinden yararlanılmıştır. Böylece yatay kesitlerde bulunmayan hareketli etkiler göz önünde bulundurularak iller arasındaki heterojenliği inceleme olanağ 1 elde edilmiştir. Panel veri analizinde tahminler için EViews 9 ve diğer testler için ise Stata 15 programları kullanılmıştır.

Bilindiği üzere, veri setinin yapısına bağlı olarak panel veri analizleri makro panel veri ve mikro panel veri olarak ayrışmaktadır. Büyük yatay kesit ve büyük zaman serisine sahip olan asimptotik makro panellerin serilerinde durağanlık koşulunun sağlanması gerekirken, büyük yatay kesit ve küçük zaman serisine sahip asimptotik mikro panellerde durağanlık koşulunun sağlanması gerekmemektedir (Baltagi, 2005: 7). Bir başka ifadeyle, küçük zaman serilerine sahip mikro panellerde birim kök testi yapılmasına gerek bulunmamaktadır. Bu nedenle, 81 il yatay kesitine ve 10 y1llık zaman serisine sahip olan panel veri seti çerçevesinde mikro panel veri analizi kabul edilmiş ve değiş̧kenlere ait serilerde durağanlık varsayımı dikkate alınmayarak çalışmada birim kök testi kullanılmamıştır.

Modelde kişi başı yerel GSYH ve suç oranı değişkenleri birer kontrol değişkeni olarak kullanılmıştır. Tiebout modeli açısından önemli olan değişkenler ise kişi başı yerel harcamalar ve kişi baş1 yerel vergi gelirleridir. Bu nedenle kuramsal olarak Tiebout modelinin geçerli olabilmesi için $\beta_{1}$ katsayısının (tercihen) pozitif, $\beta_{2}$ katsayısının ise negatif çıkması beklenmektedir. Bir başka ifadeyle, kişi başı yerel harcamalar arttıkça ve/veya kişi başı yerel vergi geliri azaldıkça net göç hızının artması Tiebout modelinin geçerli olduğu anlamına gelmektedir.

(1) nolu denklemin tahmin edilmesinden önce, uygun panel veri modeli türünü belirleyebilmek için bir takım testler uygulanmıştır. Bunlardan ilki, havuzlanmış model ile sabit etki modeli arasında tercih yapabilmeyi sağlayan $F$ testidir. Tablo 2'den de görüleceği üzere, $F$ testi olasılık değerinin 0.05 değerinden küçük olması nedeniyle havuzlanmış modelin uygun olduğunu belirten $\mathrm{H}_{0}$ hipotezi reddedilmiştir. İkinci olarak, havuzlanmış model ile rassal etki modeli arasında tercih yapabilmeyi sağlayan Breusch Pagan testi (LM testi) kullanılmıştır. Tablo 2'de BreuschPagan testi olasılık değerinin 0.05 değerinden küçük olduğu görülmektedir. $\mathrm{Bu}$ nedenle havuzlanmış modelin uygun olduğunu belirten $\mathrm{H}_{0}$ hipotezi reddedilmiştir. Analizin havuzlanmış model ile tahmin edilemeyeceği sonucuna ulaştıktan sonra, rassal etki ile sabit etki modeli arasında tercih yapabilmeyi sağlayan Hausman testi kullanılmıştır. Tablo 2'den de görüleceği üzere, Hausman testi olasılık değerinin 0.05 değerinden küçük olması nedeniyle rassal etki modelinin uygun olduğunu belirten $\mathrm{H}_{0}$ hipotezi reddedilmiştir. $\mathrm{Bu}$ nedenle çalışmamızda panel veri modeli, sabit etki yöntemiyle analiz edilmiştir. Nitekim modelimizde yatay kesit birimleri olarak Türkiye'deki 81 ilin tamamının ele alınması da, kuramsal olarak sabit etki yönteminin kullanılması gerektiğini işaret etmektedir.

Tablo 2: Panel Veri Yönteminin Belirlenmesi İçin Uygulanan Test Sonuçları

\begin{tabular}{|c|c|c|c|}
\hline Test Modelleri & Test Yöntemi & İstatistik & Olasılık \\
\hline Havuzlanmış - Sabit Etki & F Testi & 3.43 & 0.0000 \\
\hline Havuzlanmış - Rassal Etki & Breusch-Pagan Testi (LM Testi) & 101.00 & 0.0000 \\
\hline Rassal Etki - Sabit Etki & Hausman Testi & 16.74 & 0.0008 \\
\hline
\end{tabular}

Bilindiği üzere, bir regresyon analizinde hata terimleri arasında ilişki olmaması (yani otokorelasyon olmaması) beklenmektedir. Çalışmamızın veri setinde otokorelasyon olup olmadığını araştırmak üzere Bhargava, Franzini ve Narendranathan (1982) tarafından önerilen Değiştirilmiş Durbin-Watson testi ve Baltagi-Wu (1999) tarafından önerilen LBI (Yerel En İyi Değişmez) testi kullanılmıştır. Tablo 3'den de görüleceği üzere, her iki test istatistiği eşik değer olarak kabul edilen 2'nin üzerinde olduğundan, birinci dereceden otokorelasyonun olmadığını 
belirten $\mathrm{H}_{0}$ hipotezi kabul edilmektedir. $\mathrm{Bu}$ nedenle modelde otokorelasyon sorunu bulunmamaktadır.

Bir regresyon analizinde elde edilen hata terimlerinin varyanslarının sabit olması beklenmektedir. Hata terimlerinin varyansları birbirinden farklı olduğu zaman değişen varyanssorunu (heteroskedastisite) söz konusudur. Sabit etki regresyon modelinde değişen varyans sorunu olup olmadığını anlamak için Değiştirilmiş Wald testi kullanılmıştır. Tablo 3 göstermektedir ki, $\chi^{2}$ istatistiğine ait olasılık değeri 0.05 'den küçük olduğundan, sabit varyans olduğunu belirten $\mathrm{H}_{0}$ hipotezi reddedilmektedir. $\mathrm{Bu}$ nedenle modelde değişen varyans sorunu bulunmaktadır.

Tablo 3: Diagnoistik Test Sonuçları

\begin{tabular}{|c|c|c|c|}
\hline \multicolumn{2}{|c|}{ Otokorelasyon } & \multicolumn{2}{c|}{ Değişen Varyans } \\
\hline $\begin{array}{c}\text { Bhargava vd. Tarafindan } \\
\text { Değiştirilmiş Durbin- } \\
\text { Watson Test İstatistiği }\end{array}$ & $\begin{array}{c}\text { Baltagi-Wu (LBI) Test } \\
\text { İstatistĭğ }\end{array}$ & $\begin{array}{c}\text { Değiştirilmiş Wald Testi } \\
\chi^{2}(81)\end{array}$ & Olasıllı Değeri \\
\hline 2.277 & 2.570 & $76419.22^{* * *}$ & 0.0000 \\
\hline
\end{tabular}

Not: ***, \%1 düzeyinde istatistiksel olarak anlamll1ık düzeyini ifade etmektedir. Otokorelasyon testlerinde eşik değer "2" olarak kabul edilmektedir.

Modelde değişen varyans sorunu olduğu için güvenilir (robust) standart hatalar kullanılmış olup, Panel EGLS (Estimated Generalized Least Square) yöntemi ile regresyon modeli tahmin edilmiştir. Değişen varyans sorununun düzeltildiği tahmin sonuçları Tablo 4'de gösterilmektedir.

Tablo 4: Panel Veri Modelinin Tahmin Sonuçları

Bağımlı Değişken: $N G H$

Yöntem: Panel EGLS (Cross-section weights)

Dönem: 2008-2017

Yatay Kesit Sayısı: 81

Paneldeki Toplam Gözlem Sayısı: 810

White cross-section standard errors \& covariance (nod.f. correction)

\begin{tabular}{|c|c|c|c|c|}
\hline Bağımsız Değişkenler & Katsayı & Standart Hata & t-istatistiği & Olasılık Değeri \\
\hline$Y H$ & -0.003206 & 0.000378 & -8.470993 & 0.0000 \\
\hline$Y V G$ & -0.056489 & 0.005208 & -10.84586 & 0.0000 \\
\hline$Y Y$ & 0.000433 & 7.99E-05 & 5.413485 & 0.0000 \\
\hline SO & -2.056349 & 0.769018 & -2.673994 & 0.0077 \\
\hline SABITT & -0.004545 & 0.004051 & -1.121993 & 0.2622 \\
\hline $\begin{array}{l}\mathbf{R}^{2} \\
\text { Düzeltilmiș } \mathbf{R}^{2}\end{array}$ & $\begin{array}{l}0.825285 \\
0.805042\end{array}$ & $\begin{array}{l}\text { F-istatistiği } \\
\text { Olastlk (F-istatistiği) }\end{array}$ & & $\begin{array}{l}40.76915 \\
0.000000\end{array}$ \\
\hline
\end{tabular}

(1) nolu denklemin panel veri tahmin sonuçlarına göre model genel olarak anlamlıdır (Ftesti) ve açıklayıcılık gücü yüksektir (Düzeltilmiş $\mathrm{R}^{2}$ ). Tablo 4 'den de görüleceği üzere, sabit katsayı hariç tüm değişkenlerin katsayıları \%1 düzeyinde istatistiksel olarak anlamlıdır. Suç oranı ile net göç hızı arasında beklendiği gibi negatif bir ilişki çıkmıştır. Suç oranındaki bir birimlik artış, net göç hızını 2.056 birim azaltmaktadır. Kişi başı yerel GSYH da beklenen bir sonuç vermiştir ve net göç hızı ile arasında pozitif ilişki bulunmuştur. Kişi başı GSYH'deki bir birimlik artış, net göç hızını 0.0004 birim artırmaktadır. Tiebout modelinin analiz edilmesinde esas değişkenimiz olan kişi başı yerel vergi geliri ile net göç hızı arasında negatif bir ilişki olduğu tespit edilmiştir. Kişi baş1 yerel vergi gelirindeki bir birimlik artış, net göç hızını 0.056 birim azaltmaktadır. Bu sonuç Tiebout modelini yerel vergiler açısından doğrulamaktadır. Son olarak, kişi başı yerel harcamalar 
ile net göç hızı arasında negatif ilişki olduğu görülmektedir. Kişi başı yerel harcamalardaki bir birimlik artış, net göç hızını 0.003 birim azaltmaktadır. Bu sonuç Tiebout modeli açısından tercihen beklenen bir durum değildir. Zira yerel harcamaların artmasının, tüketici-seçmenlerin yerleşim tercihlerini olumlu etkilemesi beklenir. Ancak bu niceliksel beklenti, tüketici-seçmenlerin kendi yerel hizmet tercihlerini niteliksel olarak yansıtan yerlere taşındığı gerçeğini etkilememektedir.

\section{Sonuç}

Mali yerelleşme tartışmalarının maliye teorisine girmesine önemli katkıları olan Tiebout modeli, tüketici-seçmenlerin kamusal hizmet tercihlerine ve mali beklentilerine bakarak yerleşim yeri seçimlerini yapmalarının Pareto optimal bir ortam sağlayacağını ifade etmektedir. Literatürde "ayaklarıyla oy vermek" şeklinde anılan model, özellikle varsayımlarının gerçeklikten uzak olması nedeniyle eleştiri almaktadır. Ancak iktisat teorisinin birçok alanında olduğu gibi, varsayımların gerçekliğinden ziyade kendi içinde tutarlı görünen bir sistem kurulması ve piyasa araçlarıyla etkinliği sağlayan bir sonuç vermesi, bir analizin popülerliği için yeterlidir.

Tiebout modeli her ne kadar mali federalizm tartışmalarının bir parçası olsa da, mali özerkliğe sahip yerel yönetimlerin olduğu her ülke yapısı için iktisatçılar, maliyeciler, siyaset bilimciler ve nüfusbilimciler tarafindan analiz edilecek tartışma konularına ve değişkenlere sahiptir. Tiebout modelini Türkiye için test etmek amacıyla yapılan çalışmada, sadece yerel mali değişkenlerin mekânsal tercihlere olan etkisi değil, yerel iktisadi ve yerel sosyal değişkenlerin de etkisi modelimize dâhil edilmiştir. Böylece güçlü etkisinin olacağı düşünülen olası değişkenlerle de modelin açıklayıcılığının artırılması amaçlanmıştır.

Panel EGLS (Estimated Generalized Least Square) yöntemi ile tahmin ettiğimiz modelimizde net göç hızının kişi başı yerel GSYH ile pozitif ve suç oranı ile negatif ilişkisinin olduğu sonucuna ulaşılmıştır. Tiebout modelini analiz etmek amacıyla kullanılan mali değişkenlerden kişi başı yerel harcamalar ve kişi başı yerel vergi gelirlerinin ise net göç hızıyla arasında negatif bir ilişkinin olduğu tespit edilmiştir.

Yerel vergi gelirleri açısından değerlendirildiğinde Tiebout modelinin Türkiye'de geçerli olduğunu söylemek mümkündür. Bir başka ifadeyle, Türkiye'de tüketici-seçmenler kişi başı yerel vergi gelirlerinin daha düşük olduğu yerlerde yaşamayı tercih etmektedirler. Yerel harcamalar açısından değerlendirildiğinde ise Tiebout modeline dair beklenen sonuç tam olarak elde edilememiştir. Türkiye'de kişi başı yerel harcamaların arttı̆̆ illerden tüketici-seçmenlerin çok az da olsa göç etmeyi tercih ettiği görülmektedir.

Ancak Tiebout modelinde yerel harcamalar açısından bir diğer önemli nokta da, harcamaların sebebi olan yerel kamu hizmetlerinin türüdür. Nitekim Tiebout modeline göre, tüketici-seçmenler yerel kamusal hizmetler içerisinden kendi tercihlerine yakın olanların yoğun olduğu bölgelerde yaşamayı tercih edecektir. Bir başka ifadeyle, Tiebout modelinde yerel harcamalar niceliksel olmaktan ziyade niteliksel bir konudur. Bu nedenle panel veri analizimizde kişi başı yerel harcamalar ile net göç hızı arasında küçük de olsa negatif bir ilişkinin çıkması, genel olarak Tiebout modelini geçersiz kılmamaktadır.

Özetle, Türkiye'de 2008-2017 dönemi için 81 il düzeyinde Tiebout modeli yerel vergiler açısından beklenen bir sonuç verirken, yerel harcamalar açısından beklenen bir sonuç vermemiştir. Elbette yerleşim yerlerinin tercih edilmesinde başka birçok yerel faktör de söz konusu olmaktadır. Aynı şekilde tüketici-seçmenler açısından baktığımızda da, mekânsal tercihlerin yapılmasında kişisel birçok faktör de belirleyici olabilmektedir. Analizin, Tiebout modeli varsayımları çerçevesinde ve veri kısıtları içerisinde yapılmış olması, sadece yerel mali değişkenlerin mekânsal tercihler ile olan ilişkisini incelemeyi zorunlu kılmıştır. 


\section{Kaynakça}

Baltagi, B. H., \& Wu, P. X. (1999). Unequally Spaced Panel Data Regressions With AR(1) Disturbances. Econometric Theory, 15(6), 814-823.

Baltagi, B. H. (2005). Econmetric Analysis of Panel Data. West Sussex, England: John Wiley \& Sons Ltd.

Banzhaf, H. S., \& Walsh, R. P. (2008). Do People Vote with Their Feet? An Empirical Test of Tiebout. American Economic Review, 98(3), 843-63.

Bhargava, A., Franzini, L., \& Narendranathan, W. (1982). Serial Correlation and the Fixed Effects Model. The Review of Economic Studies, 49(4), 533-549.

Cebula, R. J. (1974). Interstate Migration and the Tiebout Hypothesis: An Analysis According to Race, Sex and Age. Journal of the American Statistical Association, 69(348), 876-879.

Cebula, R. J. (1978). An Empirical Note on the Tiebout-Tullock Hypothesis. Quarterly Journal of Economics, 92(4), 705-711.

Dowding, K., John, P., \& Biggs, S. (1994). Tiebout: A Survey of the Empirical Literature. Urban Studies, 31(4-5), 767-797.

Edel, M., \& Sclar, E. (1974). Taxes, Spending, and Property Values: Supply Adjustment in a Tiebout-Oates Model. Journal of Political Economy, 82(5), 941-954.

Grubb, W. N. (1982). The Dynamic Implications of the Tiebout Model: The Changing Composition of Boston Communities, 1960-1970. Public Finance Quarterly, 10(1), 17-38.

John, P., Dowding, K., \& Biggs, S. (1995). Residential Mobility in London: A Micro-Level Test of the Behavioural Assumptions of the Tiebout Model. British Journal of Political Science, 25(3), 379-397.

Munley, V. G. (1982). An Alternate Test of the Tiebout Hypothesis. Public Choice, 38(2), 211217.

Musgrave, R. A. (1939). TheVoluntary Exchange Theory of Public Economy. The Quarterly Journal of Economics, 53(2), 213-237.

Musgrave, R. A. (1956). A Multiple Theory of Budget Determination. Finanz Archiv / Public Finance Analysis, 17(3), 333-343.

Musgrave, R. A. (1959). The Theory of Public Finance. New York: McGraw-Hill.

Nechyba, T. J., \& Strauss, R. P. (1998). Community Choice and Local Public Services: A Discrete Choice Approach. Regional Science and Urban Economics, 28(1), 51-73.

Oates, W. E. (1969). The Effects of Property Taxes and Local Public Spending on Property Values: An Empirical Study of Tax Capitalization and the Tiebout Hypothesis. Journal of Political Economy, 77(6), 957-971.

Oates, W. E. (1981). On Local Finance and the Tiebout Model. The American Economic Review, 71(2), 93-98.

Oates, W. E. (2005). Toward A Second-Generation Theory of Fiscal Federalism. International Tax and Public Finance, 12(4), 349-373.

Percy, S. L., Hawkins, B. W., \& Maier, P. E. (1995). Revisiting Tiebout: Moving Rationales and Interjurisdictional Relocation. Publius: The Journal of Federalism, 25(4), 1-17. 
Sakashita, N. (1999). Dynamic Analysis of the Tiebout Model with Numerical Simulations. The Japanese Economic Review, 50(1), 61-74.

Sakashita, N., \& Hirao, M. (1999). On the Applicability of the Tiebout Model to Japanese Cities. Review of Urban \& Regional Development Studies, 11(3), 206-215.

Samuelson, P. A. (1954). The Pure Theory of Public Expenditure. The Review of Economics and Statistics, 36(4), 387-389.

Tiebout, C. M. (1956). A Pure Theory of Local Expenditures. Journal of Political Economy, 64(5), 416-424.

Türkiye Cumhuriyeti Hazine ve Maliye Bakanlığı Muhasebat Genel Müdürlüğü (2019). İller Itibariyle Mahalli Yönetim Bütçe İstatistikleri (2006-2018). Erişim tarihi: 05.07.2019, https://muhasebat.hmb.gov.tr/iller-itibariyle-mahalli-yonetim-butce-istatistikleri-2006-2018

Türkiye İstatistik Kurumu (TÜİK) (2019a). Tüketici Fiyat Endeksi. Erişim tarihi: 05.07.2019, http://www.tuik.gov.tr/PreIstatistikTablo.do?istab_id=650

Türkiye İstatistik Kurumu (TÜİK) (2019b). Yıllara Göre Il Nüfusları. Erişim tarihi: 05.07.2019, http://www.tuik.gov.tr/PreIstatistikTablo.do?istab_id=1590

Türkiye İstatistik Kurumu (TÜİK) (2019c). Illerin Aldı̆̆g, Verdiği Göç, Net Göç ve Net Göç Hızı, Genel Nüfus Sayımları - ADNKS. Erişim tarihi: 05.07.2019, http://www.tuik.gov.tr/PreIstatistikTablo.do?istab_id=1595

Türkiye İstatistik Kurumu (TÜİK) (2019d). Il Bazında Gayrisafi Yurt İçi Hasıla, İktisadi Faaliyet Kollarına Göre, Cari Fiyatlarla, NACE Rev.2, 2004-2017. Erişim tarihi: 05.07.2019, http://www.tuik.gov.tr/PreIstatistikTablo.do?istab_id=2520

Türkiye İstatistik Kurumu (TÜIK) (2019e). Suç İşlenen İle Göre Ceza İnfaz Kurumuna Giren Hükümlü Sayısı. Erişim tarihi: 05.07.2019, https://biruni.tuik.gov.tr/ilgosterge/?locale=tr 